\title{
World Wide Web
}

\section{Encyclopedia of Life Support Systems (EOLSS)}

\author{
I.E. Cock ${ }^{\mathrm{ab}^{*}}$ \\ Editor-In-Chief, Pharmacognosy Communications
}

aBiomolecular and Physical Sciences, Nathan Campus, Griffith University, 170 Kessels Rd, Nathan, Brisbane, Queensland 4111, Australia. ${ }^{b}$ Environmental Futures Centre, Nathan Campus, Griffith University, 170 Kessels Rd, Nathan, Brisbane, Queensland 4111, Australia.

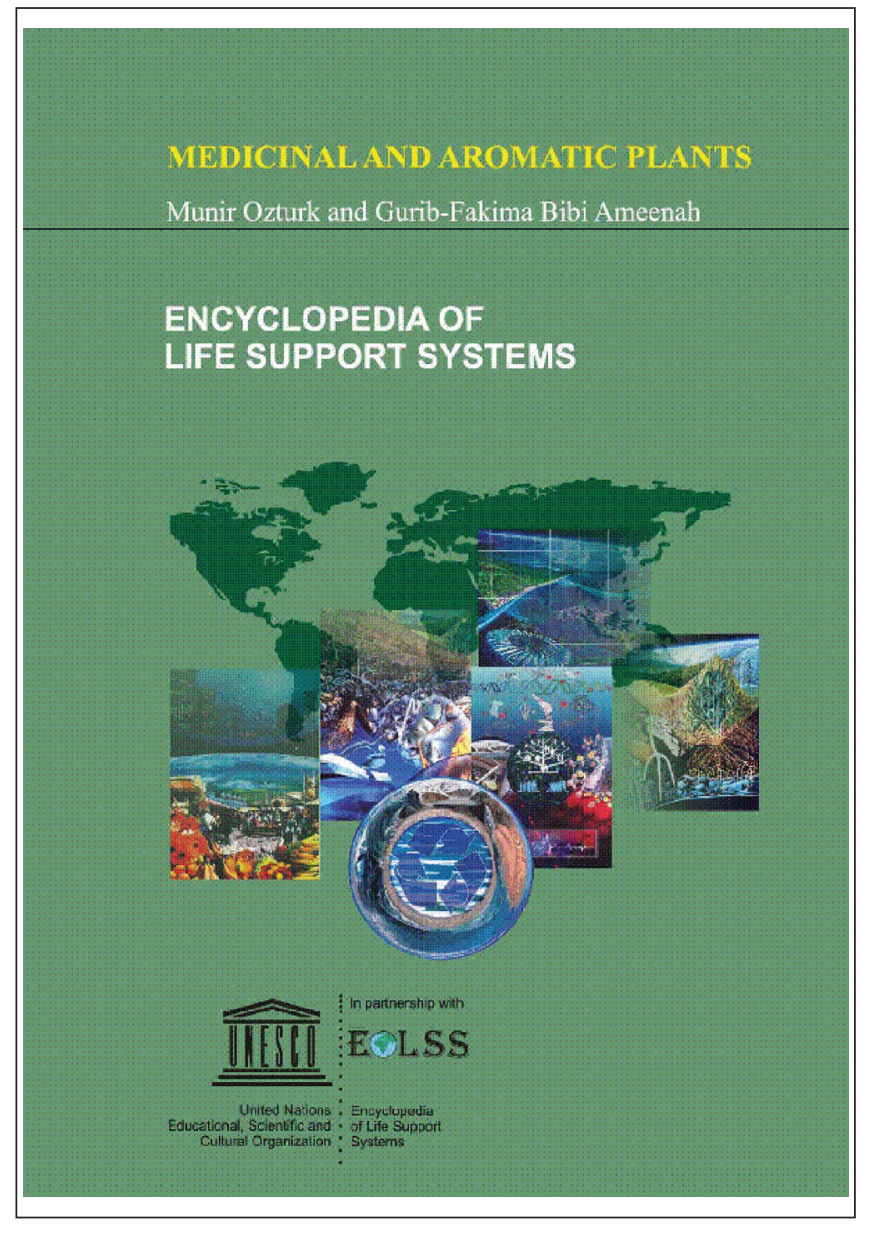

The Encyclopedia of Life Support Systems (EOLSS) (http://www.eolss.net/) is an integrated multidisciplinary online encyclopedia that is written and edited by leading researchers in their fields. EOLSS is a joint project in conjunction with the United Nations Educational, Scientific

*Correspondence: Tel.: +61 7 37357637; fax: +61 737355282.

E-mail address: editor@phcogcommn.org,

I.Cock@griffith.edu.au

DOI: $10.5530 /$ pc.2011.2.10 and Cultural Organisation (UNESCO). It is aimed at promoting health, global maintainance and all aspects of sustainable development, covering diverse themes including ecological issues, bio-innovation, sustainable production and biosecurity. All volumes are invited, with thousands of contributions from leading scholars from over 100 countries worldwide, making the EOLSS possibly the largest and most ambitious data base of its kind. The encyclopedias are designed as a useful reference guide for a wide range of users, from students beginning studies of the subject matter, through to experienced researchers and policy makers.

EOLSS differs from most encyclopedias which are organised alphabetically. Instead, EOLSS is organised into various themes and emphasises the interdependence of these disciplines. EOLSS is essentially a series of 20 encyclopedias:

- Earth and atmospheric sciences.

- Mathematical sciences.

- Biological, physiological and health sciences.

- Biotechnology.

- Tropical biology and conservation.

- Land use, land cover and soil sciences.

- Social sciences and humanities.

- Physical sciences, engineering and technology resources.

- Control systems, robotics and automation.

- Chemical sciences, engineering and technology resources.

- Water sciences, engineering and technology resources.

- Energy sciences, engineering and technology resources.

- Environmental and ecological sciences, engineering and technology resources.

- Food and agricultural sciences, engineering and technology resources.

- Human resources policy, development and management.

- Natural resources policy and management.

- Development and economic sciences.

- Institutional and infrastructural resources.

- Technology, information and systems management resources.

- Area studies (regional sustainable development reviews). 
Each of these encyclopedias is comprised of a number of volumes. There are currently more than 600 volumes across the 20 encyclopedias and this number is constantly growing. Several of these encyclopedias are of particular interest to researchers in the field of pharmacognosy. The Biological, Physiological and Health Sciences Encyclopedia is especially relevant to researchers in the field of pharmacognosy and related studies. On the day I reviewed this site there were volumes available summarising current knowledge of medicinal and aromatic plants in diverse regions of the world including Arabia, ${ }^{[1]}$ Australia,,${ }^{[2]}$ Azerbaijan, ${ }^{[3]}$ the Iberian peninsula ${ }^{[4]}$ and Turkey. ${ }^{[5]}$ Further volumes of this encyclopedia summerise the use of plant based medicines in the treatment of cancer, ${ }^{[6]}$ inflammation, ${ }^{[7]}$ diabetes, ${ }^{[8]}$ coronary disease, ${ }^{[0]}$ as well as viral, ${ }^{[10]}$ neurodegenerative ${ }^{[11]}$ and parasitic ${ }^{[12]}$ diseases.

The Encyclopedia of Chemical Sciences, Engineering and Technology Resources also has many volumes relevant to pharmacognosy researchers. Indeed, a whole series of volumes of this encyclodedia is devoted to phytochemistry and pharmacognosy. Specific volumes within this series examine the ethnobotany of natural products, ${ }^{[13]}$ the occurrence and function of natural products in plants, ${ }^{[14]}$ alkaloids, ${ }^{[15]}$ terpenes, ${ }^{[16]}$ natural products from microorganisms, ${ }^{[17,18]}$ as well as the use of natural products in the treatment of malaria ${ }^{[19]}$ and cancer. ${ }^{[20,21]}$ This is by no means a complete listing of the volumes relevant to pharmacognosy research and is outlined here merely to demonstrate the scope of the EOLSS encyclopedias. It is recommended that readers examine the EOLSS encyclopedias for usefulness to their own studies.

EOLSS aims to make its resources as widely available as possible to all global populations. Access is by subscription in most cases. However, to enable persons from economically disadvantaged and developing regions to access this information, EOLSS is made available free of charge to universities in the UN list of least developed countries (there are currently 50 countries in this category - for a full listing refer to http://www.eolss.net/), and to disadvantaged individuals worldwide. All institutions are able to access a free trial of between 60 days and 5 months by registering the details of their institution on the EOLSS site. I encourage all researchers in pharmacognosy and related fields to trial this site for themselves to determine its usefulness to their own studies. I reviewed this site on $5^{\text {th }}$ July 2011.

\section{REFERENCES}

1. Ghazanfar SA, 2011, Medicinal and aromatic plants - Arabia and Iran, in Ethnopharmacology section, Biological, Physiological and Health Sciences, Encyclopedia of Life Support Systems (EOLSS), Developed under the Auspices of the UNESCO, EOLSS Publishers, Oxford, UK, (http://www.eolss.net).

2. Cock IE, 2011, Medicinal and aromatic plants - Australia, in Ethnopharmacology section, Biological, Physiological and Health Sciences, Encyclopedia of Life Support Systems (EOLSS), Developed under the Auspices of the UNESCO, EOLSS Publishers, Oxford, UK, (http://www.eolss.net).

3. Mehtiyeva N, Zeynolova S, 2011, Medicinal and aromatic plants of Azerbaijan, in Ethnopharmacology section, Biological, Physiological and Health Sciences, Encyclopedia of Life Support Systems (EOLSS), Developed under the Auspices of the UNESCO, EOLSS Publishers, Oxford, UK, (http://www.eolss.net).

4. Uriarte-Pueyo I, Calvo MI, 2011, Medicinal and aromatic plants - Iberian Peninsula, in Ethnopharmacology section, Biological, Physiological and Health Sciences, Encyclopedia of Life Support Systems (EOLSS), Developed under the Auspices of the UNESCO, EOLSS Publishers, Oxford, UK, (http://www.eolss.net).

5. Öztürk M, Altundağ, Gücel S, 2011, Medicinal and aromatic plants (Turkey), in Ethnopharmacology section, Biological, Physiological and Health Sciences, Encyclopedia of Life Support Systems (EOLSS), Developed under the Auspices of the UNESCO, EOLSS Publishers, Oxford, UK, (http://www.eolss.net).

6. Cragg GM, Newman DJ, 2006, Plants as a source of anticancer agents, in Ethnopharmacology section, Biological, Physiological and Health Sciences, Encyclopedia of Life Support Systems (EOLSS), Developed under the Auspices of the UNESCO, EOLSS Publishers, Oxford, UK, (http://www.eolss.net).

7. Calixto JB, Campos MM, Santos ARS, 2005, Botanical analgesics and anti-inflammatory drugs, in Ethnopharmacology section, Biological, Physiological and Health Sciences, Encyclopedia of Life Support Systems (EOLSS), Developed under the Auspices of the UNESCO, EOLSS Publishers, Oxford, UK, (http://www.eolss.net).

8. King SR, Limbach C, 2006, The search for plants to manage diabetes, in Ethnopharmacology section, Biological, Physiological and Health Sciences, Encyclopedia of Life Support Systems (EOLSS), Developed under the Auspices of the UNESCO, EOLSS Publishers, Oxford, UK, (http://www.eolss.net).

9. Mahady GB, 2004, Medicinal plants for the prevention and treatment of coronary heart disease, in Ethnopharmacology section, Biological, Physiological and Health Sciences, Encyclopedia of Life Support Systems (EOLSS), Developed under the Auspices of the UNESCO, EOLSS Publishers, Oxford, UK, (http://www.eolss.net).

10. Cos P, Maes L, Vanden Berghe D, 2005, Plants and plant substances against AIDS and other viral diseases, in Ethnopharmacology section, Biological, Physiological and Health Sciences, Encyclopedia of Life Support Systems (EOLSS), Developed under the Auspices of the UNESCO, EOLSS Publishers, Oxford, UK, (http://www.eolss.net).

11. Houghton PJ, Howes MJR, 2004, The search for plants to manage neurodegenerative diseases, in Ethnopharmacology section, Biological, Physiological and Health Sciences, Encyclopedia of Life Support Systems (EOLSS), Developed under the Auspices of the UNESCO, EOLSS Publishers, Oxford, UK, (http://www.eolss.net).

12. Willcox ML, Gilbert B, 2006, Traditional medicinal plants for the treatment and prevention of human parasitic diseases, in Ethnopharmacology section, Biological, Physiological and Health Sciences, Encyclopedia of Life Support Systems (EOLSS), Developed under the Auspices of the UNESCO, EOLSS Publishers, Oxford, UK, (http://www.eolss.net).

13. Soejarto DD, Gyllenhaal C, Riley MC, Zhang H, 2011, Ethnobotany of natural products, in Phytochemistry and Pharmacognosy section, Chemical Sciences, Engineering and Technology Resources, Encyclopedia of Life Support Systems (EOLSS), Developed under the Auspices of the UNESCO, EOLSS Publishers, Oxford, UK, (http://www.eolss.net).

14. Wink M, 2011, Occurence and function of natural products in plants, in Phytochemistry and Pharmacognosy section, Chemical Sciences, Engineering and Technology Resources, Encyclopedia of Life Support Systems (EOLSS), Developed under the Auspices of the UNESCO, EOLSS Publishers, Oxford, UK, (http://www.eolss.net).

15. Cordell GA, Choi T, 2011, Alkaloids and their biosynthesis, in Phytochemistry and Pharmacognosy section, Chemical Sciences, Engineering and Technology Resources, Encyclopedia of Life Support Systems (EOLSS), Developed under the Auspices of the UNESCO, EOLSS Publishers, Oxford, UK, (http://www.eolss.net).

16. Zhang H, Qiu M, Chen J, Sun Y, Wang C, Fong HHS, 2011, Plant terpenes, in Phytochemistry and Pharmacognosy section, Chemical Sciences, Engineering and Technology Resources, Encyclopedia of Life Support Systems (EOLSS), Developed under the Auspices of the UNESCO, EOLSS Publishers, Oxford, UK, (http://www.eolss.net).

17. Gunatilaka AAL, Wijeratne EMK, 2011, Natural products from bacteria and fungi, in Phytochemistry and Pharmacognosy section, Chemical 
Sciences, Engineering and Technology Resources, Encyclopedia of Life Support Systems (EOLSS), Developed under the Auspices of the UNESCO, EOLSS Publishers, Oxford, UK, (http://www.eolss.net).

18. Murphy BT, Maloney KN, Fenical W, 2011, Natural products from marine microorganisms, in Phytochemistry and Pharmacognosy section, Chemical Sciences, Engineering and Technology Resources, Encyclopedia of Life Support Systems (EOLSS), Developed under the Auspices of the UNESCO, EOLSS Publishers, Oxford, UK, (http://www.eolss.net).

19. Sebisubi FM, Tan GT, 2011, Natural products with antimalarial activity, in Phytochemistry and Pharmacognosy section, Chemical Sciences, Engineering and Technology Resources, Encyclopedia of Life Support Systems (EOLSS), Developed under the Auspices of the UNESCO, EOLSS Publishers, Oxford, UK, (http://www.eolss.net)
20. Guilford JM,Pezzuto JM,2011,Cancer chemoprevention, in Phytochemistry and Pharmacognosy section, Chemical Sciences, Engineering and Technology Resources, Encyclopedia of Life Support Systems (EOLSS), Developed under the Auspices of the UNESCO, EOLSS Publishers, Oxford, UK, (http://www.eolss.net).

21. Cragg GM, Newman DJ, 2011, Natural products as a source of antitumor agents, in Phytochemistry and Pharmacognosy section, Chemical Sciences, Engineering and Technology Resources, Encyclopedia of Life Support Systems (EOLSS), Developed under the Auspices of the UNESCO, EOLSS Publishers, Oxford, UK, (http://www.eolss.net). 